\title{
The Manipulation of Social, Cultural and Religious Values in Socially Mediated Terrorism
}

\author{
Claire Smith ${ }^{1, *}$ (1) , Rosslyn von der Borch ${ }^{1}$, Benjamin Isakhan ${ }^{2,3}$, Sukendar Sukendar ${ }^{4}$, \\ Priyambudi Sulistiyanto ${ }^{5}$, Ian Ravenscrroft ${ }^{1}$, Ida Widianingsih ${ }^{6}$ and Cherrie de Leiuen ${ }^{1}$ \\ 1 College of Humanities, Arts and Social Science, Flinders University, Adelaide 5042, Australia; \\ rosslyn.vonderborch@flinders.edu.au (R.v.d.B.); Ian.ravenscroft@flinders.edu.au (I.R.); \\ cherrie.deleiuen@flinders.edu.au (C.d.L.) \\ 2 Alfred Deakin Institute, Deakin University, Melbourne 3125, Australia; benjamin.isakhan@deakin.edu.au \\ 3 Department of Politics and International Relations, University of Johannesburg, Johannesburg 2006, \\ South Africa \\ 4 Universitas Islam Negeri Walisongo, Semarang 50185, Indonesia; sukendar@walisongo.ac.id \\ 5 College of Business, Government and Law, Arts and Social Science, Flinders University, Adelaide 5042, \\ Australia; priyambudi.sulistiyanto@flinders.edu.au \\ 6 Universitas Padjadjaran, Bandung 45363, Indonesia; ida.widianingsih@unpad.ac.id \\ * Correspondence: Claire.smith@flinders.edu.au; Tel.: +61-4243-88925
}

Received: 28 March 2018; Accepted: 15 May 2018; Published: 22 May 2018

\begin{abstract}
This paper presents an analysis of how the Islamic State/Da'esh and Hizb ut-Tahrir Indonesia manipulate conflicting social, cultural and religious values as part of their socially mediated terrorism. It focusses on three case studies: (1) the attacks in Paris, France on 13 November 2015; (2) the destruction of cultural heritage sites in Iraq and Syria; and (3) the struggle between nationalist values and extreme Islamic values in Indonesia. The case studies were chosen as a basis for identifying global commonalities as well as regional differences in socially mediated terrorism. They are located in Asia, the Middle East and Europe. The integrated analysis of these case studies identifies significant trends and suggests actions that could lessen the impact of strategies deployed by extremist groups such as Da'esh, al-Qaeda and Hizb ut-Tahrir. We discuss the broader implications for understanding various aspects of socially mediated terrorism.
\end{abstract}

Keywords: socially mediated terrorism; the Islamic State; Da'esh; Hizb ut-Tahrir Indonesia; signalling theory; semiotics; cultural heritage; social media; Paris attacks; conflict in Syria and Iraq

\section{Introduction}

What the extremists want is to divide our world along fault lines of religion and culture and so a lot of people in the West may have stereotypes against Arabs and Muslims.... But really this fight is a fight between the civilized world and a bunch of crazy people who want to take us back to medieval times. Once we see it that way, we realize that this is about all of us coming together to defend our way of life. Queen Rania of Jordan (Miles 2015).

Queen Rania of Jordan's characterisation of the Paris attacks of 13 November 2015 as part of a wider conflict between cultural values accords with similar statements by President Barak Obama of the United States (Obama 2015) and British Prime Minister, David Cameron (Cameron 2015). As these world leaders recognize, terrorist acts by extremist groups emerge from and seek to amplify, conflicts in social, cultural and religious values. The issue that is of particular interest for this paper is how both 
$\mathrm{Da}^{\prime} \mathrm{esh}^{1}$ and Hizb ut-Tahrir use social media to manipulate the social, cultural and religious values of particular audiences and to widen the fault lines identified by Queen Rania of Jordan: How do conflicting social, cultural and religious values play out symbolically across the globe? How do the actions of others further socially mediated terrorism? This paper analyses social, cultural and religious values in the context of three case studies: (1) the attacks in Paris, France, on 13 November 2015; (2) the destruction of cultural heritage sites in Iraq and Syria; and (3) the struggle between nationalist values and extreme Islamic values in Indonesia.

The case studies were chosen as a basis for identifying global commonalities as well as regional differences in socially mediated terrorism. They are located in Asia, the Middle East and Europe. Though they are both extremist organisations, Da'esh and Hizb ut-Tahrir represent different extremes on the spectrum of these organisations. While Da'esh is firmly situated within jihadi frameworks, Hizb ut-Tahrir Indonesia operates outside the jihadi milieu. The selection of jihadi and non-jihadi organisations for our case studies widens the purview of this study and increases our ability to obtain a nuanced understanding of the sophisticated global communication strategies that extremist organization are developing across the globe.

\section{Background}

This study considers how Da'esh and Hizb ut-Tahrir Indonesia manipulate the social, cultural and religious values of target groups to strengthen their socially mediated terrorism. Following Smith et al. (2016), socially mediated terrorism is defined as 'the use of social and networked media to increase the impact of violent acts undertaken to further a social, political and/or religious cause with the aim of creating physical, emotional or psychological suffering that extends beyond the immediate audience.'

Social media is integral to the communication strategies of extremist groups such as Da'esh and Hizb ut-Tahrir. The modern communications environment provides an opportunity to garner public attention for extremist causes and, through this attention, to recruit support from sympathisers and increase the impact of extremist actions. Over a few short years, Da'esh developed fine-honed media skills, including the capacity to post around 90,000 messages a day online (House of Commons 2015). Thomas Hegghammer, Director of Terrorism Research at the Norwegian Defence Research Establishment, has described Syria as 'the most socially mediated conflict in history,' pointing to the 'enormous amount of audio-visual documentation produced by rebels themselves, documenting the things they do' (House of Commons Home Affairs Committee 2014, p. 48). These materials are not collected haphazardly but as part of a sophisticated global communication strategy.

Current social media networks can quickly reach millions of people, some of whom are particularly vulnerable to Da'esh's recruitment strategies. These groups include Muslims (often nominal Muslims initially) who feel disenfranchised, particularly those living in the West, as well as Muslims across the globe who feel ready to participate in a cause and those who have long worked for Islamic causes in a localized way (IPAC 2017a). Some have been working on that same cause in isolation or in small groups but can now find community in larger groups. Nominal Muslims are drawn into more intensive practice and non-Muslims convert. While social media is used for active recruitment, it can have a role as part of normal communication strategies among groups of friends:

Social media affects recruitment simply by linking people up-Facebook, for example. When someone travels to Syria and posts pictures from there and his friends see those pictures, those friends are more likely to be inspired to go. That is not really propaganda; that is just regular information conveyed through online social media that then facilitates recruitment (House of Commons Home Affairs Committee 2014, p. 48).

1 Though it is best known as the Islamic State, we refer to this organisation as Da'esh, following international practice aimed at denying it legitimacy as either Islamic or a State (see Dragovic 2015). 
Social media can play a covert role in extremist actions by reinforcing the social, cultural and religious values that underpin the acts of individuals and by providing people who may work alone with the sense that they are supported by a larger cause.

\section{Semiotics, Praxis and Signalling}

The theoretical framework for this research draws upon three interlocking approaches to the analysis of communication: semiotics, praxis and signalling. Semiotics interprets sounds or images as part of a system of signification and communication (De Saussure [1916] 1983). Social practice/praxis develops the notion that systems of signification are situated both socially and historically and, moreover, that symbolic behaviours are aimed towards the achievement of specific social goals (Bourdieu 1977; Giddens 1984). Signalling theory focusses on the evolution of socially motivated cooperation at small and large social scales (e.g., Bulbulia and Sosis 2011).

Broadly speaking, signals convey information from the signaller to the recipient. Signals can be honest or deceptive. Some signals are false because the signaller, though well intended, holds a mistaken view. If the President has declared war on North Korea but a signaller believes otherwise their signal "The President has not declared war on North Korea" will be unintentionally false. But not all false signals are unintended. Signals can be used to manipulate the recipient and both true and false signals can achieve this end (Guilford and Dawkins 1991). For example, in a xenophobic community a politician may find it useful to truthfully signal a crime committed by a member of an immigrant community to heighten anti-immigration rhetoric, or it may be useful for a politician to falsely signal to their electorate that the economy is doing well.

It is important that people ascertain whether a signal is true or false. Such an assurance can be inferred through the costliness of the signal (Brokensha et al. 2016). The classic example of costly signalling is the extravagant plumage of the male peacock. Female peacocks preferentially mate with fit males (in the evolutionary sense), so males need to signal they are fit. Since only very fit male peacocks can afford to carry the plumage-weak males who exhibited such plumage would be easy prey-the plumage truthfully signals the fitness of the male. Carrying the plumage is costly-a cost that weak birds cannot pay—and so the plumage acts as a reliable signal of the male's fitness (Zahavi 1975, 1997). Other forms of costly signalling rely on the investment of a significant amount of time, money or other limited resources (Bulbulia and Sosis 2011). The greater the investment, the more likely that the signal is 'honest,' since the substantial investment of limited resources impinges upon the signaller's capacity to invest in alternatives. From this viewpoint, religious beliefs, behaviours and rituals function as costly signals of cooperative intent (e.g., Murray and Moore 2009).

The materials analysed in this study were located on a range of internet and social media sites, including Facebook and Twitter and on online news coverage of the events. The data include promotional material produced by Da'esh and circulated on the internet. As Resnyansky (2015) points out, different types of society are characterised by different symbolic schemes. Accordingly, these materials were analysed in terms of the information they signalled to different social groups.

\section{Case Studies}

Three case studies were selected in order to identify global commonalities as well as regional differences in socially mediated terrorism. These case studies are located in Asia, the Middle East and Europe. The first case study is the series of attacks that included the Bacalan Theatre in Paris, France on 13 November 2015. The second is the destruction of cultural heritage sites in Iraq and Syria and the third is the struggle between nationalist values and extreme Islamic values in Indonesia.

\subsection{Paris: 13 November 2015}

A series of attacks on Paris by Da'esh were undertaken on 13 November 2015, resulting in the deaths of 130 people. Da'esh's representational coverage of the attacks suggest deep planning. Sophisticated and polished media materials were distributed immediately following the attacks, 
designed to target specific audiences. The high cost of these signals served to establish the legitimacy of Da'esh's campaign. One clear target was the five million young Muslims who live in France. Among Da'esh's online recruitment materials are high-quality online videos calling young French Muslims to join other young French nationals who have joined Da'esh (CNN 2015). As Leander (2016, p. 18) points out, the commercial quality of such materials 'gives each a reassuring stamp of normality.' She contends that:

These are not marginal aspects of DA'ESH politics. Rather, they are important for broadening the range of potential Western recruits the videos can speak to and crucial for enrolling them in circulating the videos (Leander 2016, p. 18).

Informed by such strategies, Da'esh's media outputs concerning the November Paris attacks included a polished and sophisticated image of an intrepid fighter walking away from a Paris that is engulfed in flames. This image keys into the heroic tropes of online gaming, particularly Prototype and inFAMOUS, (Figure 1). In a similar vein, the logo of the Islamic State Health Services (ISHS) mimics that of the British National Health Service (Leander 2016, p. 16). Given a creation strategy of emulation, it is clear that the Paris image was designed to garner new recruits-to turn virtual warriors into actual warriors. The image is inscribed with both Arabic and French text "France under fire."

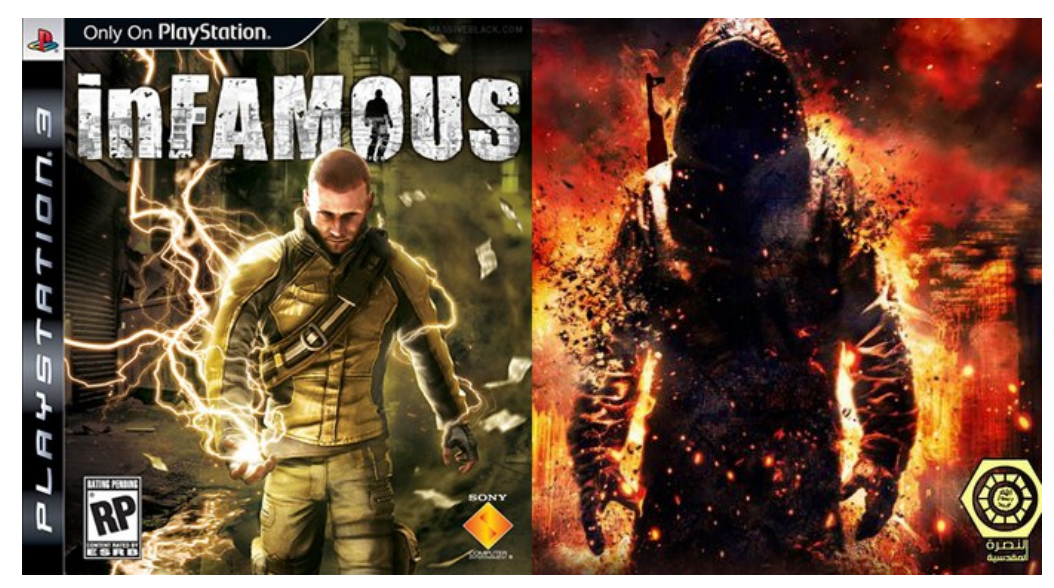

Figure 1. A polished, pre-prepared representation of the Paris attacks by Da'esh, keying into the iconography of video games and the values of the young people who play them.

A sense of Da'esh's invincibility was projected through an image in which the Eiffel Tower was redesigned as a triumphal arch with Da'esh's flag flying victoriously on top. The tower is illuminated from below. It points to the heavens and a God-given victory (Figure 2). The inclusion of a road running through the Eiffel Tower provides a sense of speed, change, even progress. In Arabic, the white text states "We are coming, France" and the yellow text states "The state of Khilafa."

There were conflicting responses on social media. Da'esh supporters celebrated on Twitter, with threats of further action, especially against the United States (SITE Intelligence Group Enterprise 2015). This may have been predictable. What was not predictable was the emergence of the blue, white and red lights social action campaign to show support for the Paris victims and, tangentially, the democratic values of liberty, equality and fraternity. Blue, white and red lights shone in major cities throughout the world, including the US, Britain, Europe, Australia, New Zealand, China, Japan, Taiwan and across South America (Rodriguez 2015). These lights were shown in few countries with Muslim majorities, though they were displayed in Egypt, Saudi Arabia, Malaysia and the UAE. Support for the Paris victims was also embedded in a parallel Facebook function that allowed members to activate a blue, white and red filter (Horton 2015).

At first glance, the social media responses to the Paris attacks were caring approaches to such a tragedy. However, these actions inadvertently furthered Da'esh's agenda by highlighting conflicting 
cultural values between different peoples and widening small fissures. As the blue, white and red activism played out around the globe it began to transform into a symbolic manifestation of an 'us' and 'them' mentality. Such a division supports xenophobic forces, which itself steers recruits towards Da'esh. Muslim countries were in an invidious position: display the lights and be vulnerable to being characterized as lackeys of the West, or do not display the lights and appear unsympathetic to the victims. This question was invidious at a personal level. Many Muslim people, particularly those who are recent immigrants, find themselves exploited and condemned to poverty by neo-liberal economic models. The blue, white and red activism put them into a difficult position. They felt sympathy for the victims. However, they were bitter about how they were being treated by the 'West,' including France.

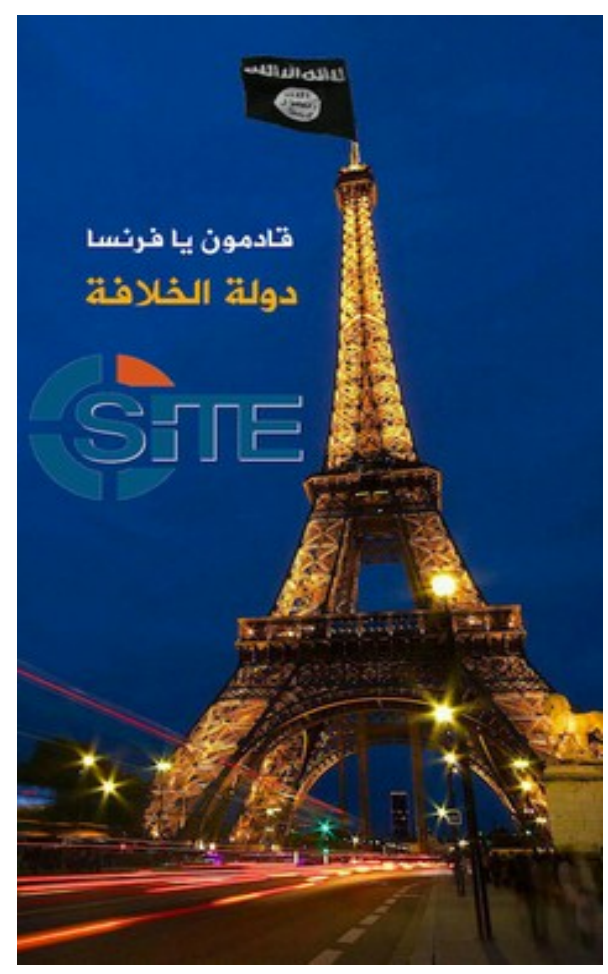

Figure 2. The Eiffel Tower redesigned as a triumphal arch with Da'esh's flag flying victoriously on top.

The complexities and contradictions of action in such circumstances play out through symbolic communication (Figure 3). As visual artist and activist Charlotte Farhan, editor of the online magazine Art Saves Lives International, pointed out on Twitter and Facebook, the blue, red and white campaign emerged as support for the victims in Paris but was not enacted for victims of comparable attacks in other places (Lavender 2015). Why did similar global campaigns not arise in support of the 90 people killed by bombings on 11th October in Ankara, Turkey, (Letsch and Khomami 2015) the 43 people who were killed by bombings in Beirut, Lebanon, on 12th November (Barnard and Saad 2015) or the 26 people killed in Bagdad, on 13 November 2015 (The Associated Press 2015)? While this could be attributed partially to a level of war-weariness in relation to conflicts in the Middle East, it is also likely to be related to Paris' iconic status. In a similar manner to the destruction of the World Trade Centre in New York in 2001, the attacks in Paris held a personal and symbolic dimension for the many millions of people who have visited this city. As Coller (2015) points out, an attack on Paris is likely to make the front page. However, the global campaign in support of the Paris victims highlighted the absence of that level of support for people who suffered similar atrocities in other parts of the world. In a system that celebrates liberté, égalité and fraternité, all lives are not mourned equally. The global manifestation of these values supported Da'esh's agenda. 


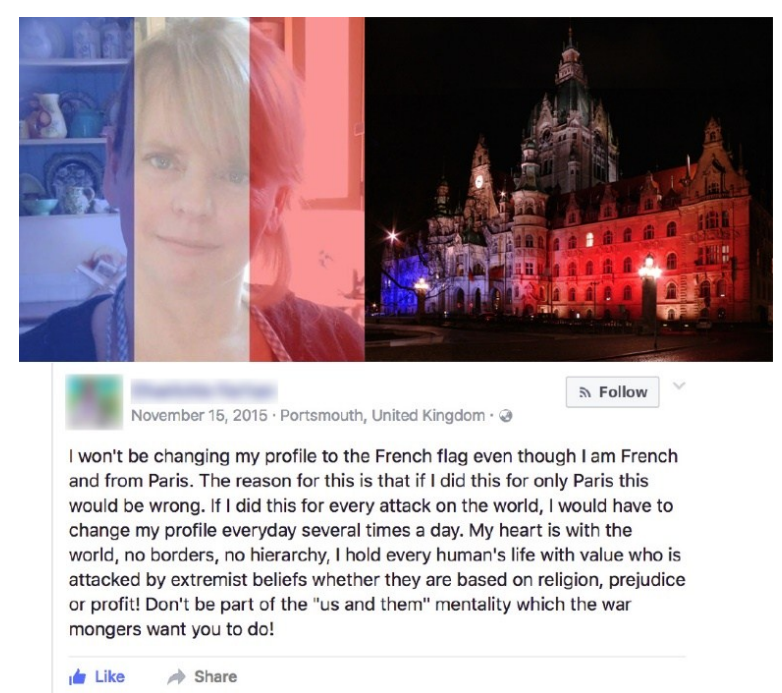

Figure 3. Conflicting approaches to the blue, white and red campaign in support of victims of the terrorist attack in Paris, 13 November 2015.

\subsection{The Destruction of Cultural Heritage Sites in Iraq and Syria}

The second case study concerns the destruction of cultural heritage sites in Iraq and Syria. In the same way that lamenting the attacks on Paris can create or exacerbate a polarised worldview, so too can reactions to Da'esh's attacks on heritage sites. There are two key points. Firstly, the international community and global media framed the damage done by Da'esh at the Mosul Museum and the ancient sites of Palmyra or Nimrud as random by-products of wanton terror or as moments of unrestrained barbarism. The United Nations Security Council condemned the attack on the Mosul Museum as part of the 'ongoing barbaric terrorist acts in Iraq by ISIL' (Charbonneau 2015); UNESCO described the destruction of archaeological remains in Palmyra as evidence of 'how terrified by history and culture the extremist are ... and exposes [their heritage destruction] as expressions of pure hatred and ignorance' (UNESCO 2015). More specifically, UNESCO Director General Irina Bokova reacted to the destruction of the ancient Assyrian capital of Nimrud by arguing that such attacks were underpinned by 'propaganda and hatred' and that 'there is absolutely no political or religious justification for the destruction of humanity's cultural heritage' (Bokova 2015).

One of Da'esh's tactics is to elicit outrage from the West in order to reinforce perceptions of strength and facilitate local territorial control and expansion (Smith et al. 2016). Given the high value that Western cultures place on cultural heritage sites, it is a relatively simple matter to elicit this outrage through the dissemination of images that record the destruction of heritage sites such as the Temple of Bel, Palmyra, Syria (Figure 4, see also Worley 2016). In 2002, Colwell-Chanthaphonh (2002), analysed the impact of internet news coverage and associated social media such as internet message boards, of the destruction of the Buddhas in the Bamiyan Valley, Afghanistan in 2001. His work highlighted how differences in social, cultural and religious values informed reactions to this destruction. Some of the messages revealed attitudes to cultural heritage destruction that may be surprising to those who are steeped in Western values:

Saturday, 03/03/01, 1:59:07 p.m. (\#383)14

As a Buddhist, I must say that, from a religious perspective, it makes no difference whatsoever if these statues are destroyed or if they are saved. They are merely representations of a man and they, like everything else, are impermanent and in a world of constant change-nothing lasts forever.... 


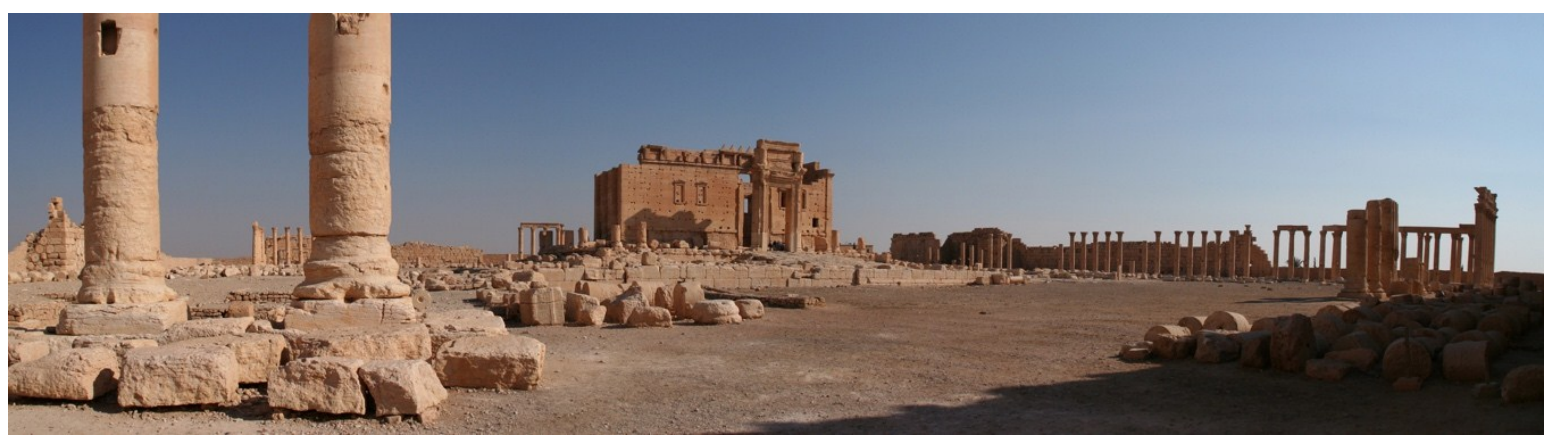

Figure 4. The Temple of Bel, Palmyra, Syria, in December 2008, prior to its destruction by Da'esh in August 2015.

Since this time, vast changes in the media landscape, including the establishment of Facebook in 2004, Twitter in 2006 and Instagram in 2010, have provided new spaces for individuals and groups to express their views without the mediation of a third party. Combined with a transformation in the nature of conflicts, these changes are such that social media can now constitute a threat to cultural heritage. Within this rapidly evolving media landscape World Heritage sites are particularly vulnerable to extremists who seek maximum impact for their political agendas (Smith 2015).

The acts of cultural heritage destruction undertaken by Da'esh are much more than mere moments of barbarity, ignorance or propaganda devoid of political or religious justification (Shahab and Isakhan 2018). Instead, their iconoclasm is carefully articulated and deliberately designed, drawing on historical precedent and key Islamist principles to construct a coherent theological framework and to establish ideological purity and political homogeneity towards the creation of a new and serene 'Islamic State' (Isakhan and Zarandona 2018, p. 4). The religious and political dimensions to the iconoclasm conducted by Da'esh are evident throughout their propaganda outlets. In terms of religious iconoclasm, Dabiq is situated within an extremist Salafi/Wahhabi interpretation of Islam with specific religious rhetoric providing the theological framework that underpins their iconoclasm. For example, Da'esh frequently assert a temporal and spiritual link between their iconoclasm and key figures of Islamic history. They repeatedly emphasise the importance of following the path of the Prophet Ibrahim, the Prophet Muhammad and his companions (Dabiq 2015b, pp. 26-29). For example:

the actions of the mujāhidīn [holy warriors] had not only emulated Ibrāhīm's ... destruction of the idols of his people and Prophet Muhammad's ... destruction of the idols present around the Ka'bah when he conquered Makkah but had also served to enrage the kuffār, a deed that in itself is beloved to Allah (Dabiq 2015a, p. 22).

In citing such historical precedent, Da'esh seeks to draw theological parallels between their actions and those of the founding figures of Islamic monotheism and of the first 'Islamic State.' In terms of the political dimension to their iconoclasm, issue one of Dabiq includes a transcription of Da'esh leader Abu Bakr al-Baghdadi's speech at the Grand Mosque of Mosul in which he announced the formation of the new Islamic State in June 2014. In it, the self-proclaimed Caliph warns the world that:

The Muslims today have a loud, thundering statement and possess heavy boots. They have a statement to make that will cause the world to hear and understand the meaning of terrorism and boots that will trample the idol of nationalism, destroy the idol of democracy and uncover its deviant nature (Dabiq 2014, p. 8).

Here, the principle of iconoclasm is extended beyond the relics and monuments of ancient civilisations, to the 'Western' political ideologies of 'nationalism' and 'democracy.' More to the point, Da'esh seeks to connect these ideologies to the sites of ancient Mesopotamia or the Greco-Roman world. For example, in one Dabiq article documenting their destruction, they state: 
The kuffār [unbeliever] had unearthed these statues and ruins in recent generations and attempted to portray them as part of a cultural heritage and identity that the Muslims of Iraq should embrace and be proud of. Yet this opposes the guidance of Allah and His Messenger and only serves a nationalist agenda (Dabiq 2015a, p. 22).

In this quote, Da'esh details two dimensions to their political iconoclasm. Firstly, it is an attack on the kuffar - presumably Westerners who, as part of the colonial period not only drew the modern borders and created the contemporary states of the Middle East but also excavated Mesopotamian archaeological sites and placed them in public museums to be admired. Following the end of colonial oversight in the mid twentieth century came the arrival of secular nationalist governments who sought to use the rich history of Iraq and Syria to inculcate a sense of collective identity (Baram 1991; Wedeen 1999). Attacks on pre-monotheistic sites are therefore not just an attack on the sins of polytheism and idolatry but also an attack on the Western colonial powers who unearthed the ancient relics and designed the modern state, as well as an attack on an entire epoch of state produced symbols that manipulated the region's rich history to serve their own 'nationalist agenda' (De Cesari 2015).

The attacks on pre-monotheistic sites are also a broader rejection not just of polytheism, colonialism and the modern state but also of the secular liberal norms that are enshrined within institutions such as the museum or multilateral bodies such as UNESCO (Gamboni 2001; Winter 2014). For example, in March 2015 UNESCO's Bokova issued a statement reacting to the destruction of heritage sites at the hands of the Da'esh, referring to them as a 'war crime' (Bokova 2015). Knowing that UNESCO was powerless to stop them, the following month Da'esh showed their clear disdain for such rhetoric in their Al-Hayat video filmed at the World Heritage Listed city of Hatra. The film not only shows militants using sledgehammers and assault rifles to destroy priceless reliefs engraved into the walls of the ancient fortress city, it also features a bold repost to Bokova: 'Some of the infidel organisations say the destruction of these alleged artefacts is a war crime. We will destroy your artefacts and idols anywhere and Islamic State will rule your lands' (Al-Hayat 2015, cited in Isakhan and Zarandona 2017).

A second dimension is worth consideration. In much the same way that the 'West' appears to care more about terrorist attacks in Paris than in Baghdad, it also appears to care more about heritage sites connected to the foundational myths of Western civilization than Islamic sites. Consider the outcry over sites featured in the Bible, such as the Assyrian capitals of Nineveh and Nimrud, or Greco-Roman sites such as Palmyra, when compared to the vast array of Islamic sites that have been damaged or destroyed by Da'esh. It is important to note that while a Mesopotamian artefact, or a Greco-Roman site are clearly important in terms of their heritage value, the Middle East's rich Islamic history may arguably hold more 'significance' to the everyday lives of many ordinary Syrians or Iraqis who derive elements of their identity from these sites.

As just one example, for the bulk of Syria and Iraq's Shia populations, various Shia Islamic monuments-shrines, mosques, schools and other buildings-may hold far greater significance and therefore more 'heritage value,' than, say, a Babylonian statue destroyed in a museum, or a cylinder seal looted from an archaeological mound. Since the onslaught of Da'esh across vast swathes of Syria and Iraq, the Shia people and their heritage sites have suffered terribly. One prominent example is the gold-domed Sayyida Zaynab mosque and shrine in southern Damascus which has come under repeated attack from at least as far back as October 2012. For Shia Muslims, the shrine is sacred as it is thought to house the remains of a significant female historical figure (Isakhan 2018). Another example occurred over three days in mid-2014, when Da'esh went on a rampage across northern Iraq destroying untold numbers of Shia mosques and shrines. For example, in just one Shia-majority town of Tal Afar, they destroyed a shrine dedicated to a founding figure of Shia Islam, Aqeel ibn Abi Talib and the mosque of Imam Sadiq, associated with the sixth Imam and a revered scholar (Danti et al. 2015, pp. 54-84). The neglect of coverage or concern for these sites in the Western media or by multi-lateral bodies such as UNESCO is indicative of a cultural hubris that is not lost on the people of the Middle East: our lives are more important than your lives; our heritage sites are more important than your 
heritage sites. In other words, one of the many failings of attempts to interpret heritage destruction in Syria and Iraq has been the overwhelming reliance on normative assumptions about what constitutes 'heritage,' seen as it has been through the lens of Western culture, at the expense of cataloguing the destruction done at sites of everyday significance to ordinary Syrians or Iraqis.

\subsection{National Values versus the Values of Radical Islam}

Our third case study concerns the struggle between national values and the values of radical Islam in Indonesia. The organization chosen for this case study is the ultra-conservative Islamist group, Hizb ut-Tahrir Indonesia (HTI). The genesis of HTI was in Al-Quds (Jerusalem, Palestine) in 1953. Since then it has successfully developed a transnational network covering more than 40 countries (Setiawan 2018, p. 14). When it was established in the early 1980s HTI affiliated with Al-Baghdadi. The official name (HTI) was first used in May 2000 (Rubino et al. 2017, p. 245).

While Da'esh and Hizb ut-Tahrir are both extremist organisations, they represent different extremes on this spectrum. Da'esh is firmly located within jihadi frameworks, while Hizb ut-Tahrir Indonesia stands outside the jihadi milieu. Though they are separate organisations, the similarities in their flags (Figure 5) signal some commonalities in social, cultural and religious values. At a very basic level, both organisations are joined by the notion of Caliphate that breaks down divisions between Muslim countries. Moreover, Hizb ut-Tahrir Indonesia's active support for Da'esh is indicated in its participation in protests against Syria's President Bashar al-Assad in Surabaya, Indonesia, in 2012. (Figure 6).

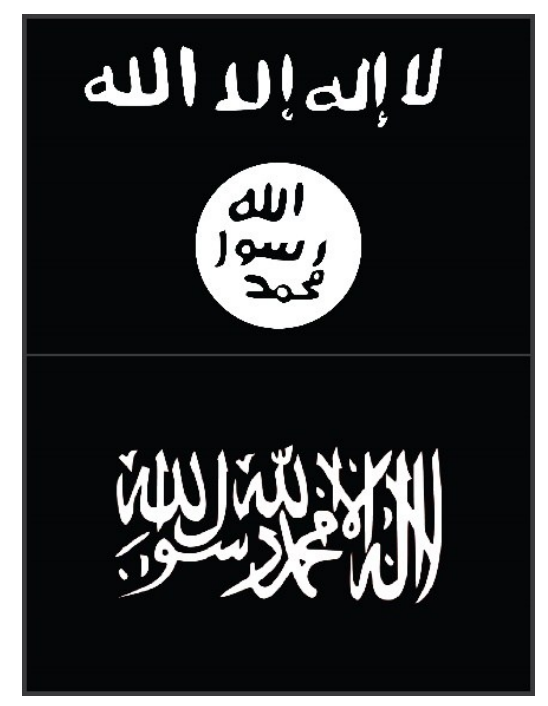

Figure 5. Variant of the flag used by the Islamic State/D'aesh (top) and the Flag of Hizb ut-Tahrir (bottom).

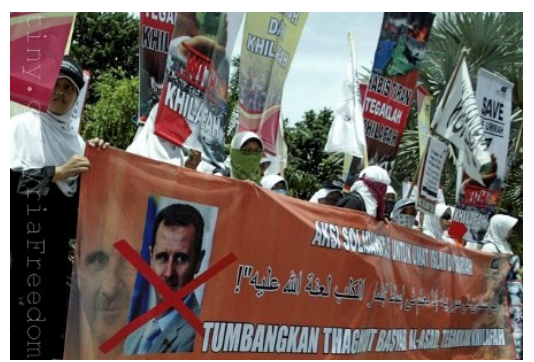

Figure 6. Indonesian members of the Hizbut Tahrir Indonesia (HTI) attend a protest against Syria's President Bashar al-Assad in Surabaya on 3 March 2012, courtesy Freedom House. 
Indonesia is one the greatest user of social media in the world, with an estimated 143 million internet users in 2017 (Yuniarni 2018). Ninety percent of Indonesian internet users are on social media. Facebook, Twitter and Telegram are the three most accessed platforms. Indonesians are the fourth most prominent Facebook users following the USA, Brazil and India (Indonesia Ministry of Communication and Information 2018).

In July 2017, Hizb ut-Tahrir Indonesia (Party of Liberation) was banned by the Indonesian government. This organisation distinguishes only two kinds of countries: the Islamic State (Dar al Islam), which consists of those who follow Islamic Law (Shari'a) and the Infidel State (Dar al-Kufr), which consists of those who do not follow Islamic Law. The HTI believes that Islamic laws consists of spiritual believe (aqidah ruqiyyah) and political ideology (aqidah siyasiyyah). For this, the HTI spoke person, Ismail Yusanto, urge all Moslem in the world to practice Islamic way of life through Shariá Law and lead by a Caliph (Setiawan 2018, p. 15). Therefore, Hizb ut-Tahrir Indonesia strives to change the foundation of the Indonesia state. Its views can be found in its digital footprints, including a video of HTI's birthday anniversary on 2 June 2013, in Senayan, Jakarta, which features an oration by some of HTI's top rank. This video identifies four objectives for Hizb ut-Tahrir Indonesian members:

1. To change the ignorance (jahiliyyah) law as a result of democracy into Shari'a law;

2. To change power from the hands of the owners of capital to the hands of (Muslim) people (ummah);

3. To destroy the national barriers that divide Muslims; and

4. To appoint one caliph to unite Muslims.

The HTI campaigns focuses on establishing the Transnational Islamic Imperium. The HTI Leader K.H. Muhammad Al-Khaththath, argues that any countries, including Indonesia, could start the formation of the Transnational Islamic Imperium (Setiawan 2018, p. 16). The HTI judges the Indonesian State ideology (Pancasila, see Morfit 1981) as kuffär ideology. The disagreement on Pancasila is cited by Ainur Rafiq from HTI in a circulation letter entitled Al-Banshasila Falsafah Kufr laa Tattafiq ma'a al-Islaam (Setiawan 2018, p. 17). These views led Mahfud MD, a Nahdlatul Ulama scholar and the former Head of Constitutional Court, to surmise that HTI is a radical organisation. In a televised debate, Mahfud MD argued that the radical feature of HTI is its endeavour to change the foundation of the Indonesia state, Pancasila (five pillars of the state), the state ideology which promotes diversity and pluralism. Mahfud MD rejected the idea of a Khilafah (Caliphate), which is endorsed by Hizb ut-Tahrir's Indonesian supporters such as Ismail Yusanto and Felix Siaw. Moreover, he asserted that in the primary sources of Islam, the Qur'an and the Sunna (tradition) of the Prophet, there is no instruction on the specific teaching on the system of politics, state administration and the rule of law and that this is left to Muslims in accordance to the demands of their particular contexts. Certainly, the Islamic world recognizes many different systems of government. Among these are the mamlakah system (kingdom), the emirate system, the sulthoniyya system (sultanate) and the jumhuriyya system (republic).

Some of the strongest advocates against radical Islam in Indonesia are the two prominent Muslim organisations, Muhammadiyah and Nahdlatul Ulama. With a combined following of some sixty million people, these organisations have instigated social media campaigns that disseminate the Islamic principles of justice, diversity and tolerance. These organisations have been involved in the soft power approach taken by the Indonesian government to debunk radical interpretations of Islamic teachings. Both organisations support education, cultural engagement and social and economic development. Nahdlatul Ulama, a conservative Sunni Islamic group, maintains that Indonesia's national identity needs to include all religious groups (Nahdlatul Ulama 2018). Muhammadiyah (2018) also promotes a modern Islam free of superstition and syncretism.

The leaders of both groups have used social media to pro-actively advocate against the tenets of radical Islam. Said Aqil Siradj, Chair of the Central Board of Nahdlatul Ulama, invited Nahdlatul Ulama's youths to use social media to spread friendly interpretations of Islam and debase Wahhabis' radical views. The video was uploaded on YouTube by IMNU Official. Responding to this message, IPNU and IPPNU (Nahdlatul Ulama student organisations) of the Mojowarno sub-district, of 
Jombang District, initiated a '1000 Status of Facebook Movement/Gerakan 1000 Status Facebook' (Nahdlatul Ulama 2017). In addition, some prominent Nahdlatul Ulama's figures such as Ahmad Mustofa Bisri (Gus Mus) and Nadirsyah Hosen are active users of social media. Hosen is the chair of Syuriah Nahdlatul Ulama and is a Professor at Monash University. His views on countering the idea of HTI's khilafa can be found in his Facebook page 'Nadirsyah Hosen.' Muhammadiyah's use of social media includes the Facebook accounts Muhammadiyah and Pemuda Muhammadiyah. On an individual level, Takdir Ali Syahbana, a Muhammadiyah activist, initiated 'Movement to follow [Muhammadiyah's] Fatwas/Gerakan Patuh Tarjih.' Through Facebook, he has disseminated Muhammadiyah interpretations of Islamic teachings compiled in the book 'Muhammadiyah's Fatwas/Putusan Tarjih Muhammadiyah.' His efforts aim to protect members of Muhammadiyah from following radical views.

In the view of Director General of Political and Nation State, Indonesian Ministry of Home Affairs, Tanribali Lamo, HTI is considered as an illegal organization due to its disagreement on Indonesian State ideology as set out in Indonesian Constitution (Setiawan 2018, p. 17).

In 2017, this soft power approach was combined with a hard power approach against radicalisation through the issuance of PERRPU (a government regulation in lieu of law) No. 2, 2017, on Mass Organisation. Article 59 of the law states that 'mass organisations are prohibited from embracing, developing and disseminating any teachings or ideologies contrary to Pancasila.' The banning of HTI by the Indonesian government follows the banning of Hizb ut-Tahrir by Malaysia in September 2015 and an earlier banning of Hizb ut-Tahrir by other countries such as Egypt, Jordan and Syria. However, as HTI has millions of followers in Indonesia, its influence is significant and it is believed to work clandestinely.

\section{Discussion}

In this paper, we have discussed how social media is used to manipulate the social, cultural and religious values of target groups to increase the global impact of Da'esh and Hizb ut-Tahrir Indonesia. We have discussed how other groups have used social media in their responses to extremist threats by Da'esh and Hizb ut-Tahrir Indonesia. In this section of our paper we identify significant trends, suggest actions that could lessen the impact of Da'esh and Hizb ut-Tahrir's strategies and discuss the broader implications for understanding various aspects of socially mediated terrorism.

\subsection{The Appeal of Da'esh and Hizb ut-Tahrir Indonesia}

Da'esh and Hizb ut-Tahrir Indonesia appeal to two distinct cohorts. For extremists, the appeal lies with their particular form of religious piety: righting of the injustices of colonialism, continuing the religious wars of the Crusades and the aim to establishing an Islamic state that is not bounded by international borders. For moderates, these groups are able to strike a chord by drawing on social and cultural issues with a broader appeal. These include asserting an identity that is not fettered by the material reminders of historical invasions by the West, redressing economic inequality and retaliation for the casualties of wars in the region perpetrated by the West.

Certainly, Da'esh's media materials consistently speak to and amplify, perceptions of racism, inequality and oppression. These issues are directly addressed in a themed issue of Dabiq entitled Wala and Bara versus American Racism:

The example of Ibrāhīm ... is for one to be prepared to reject his own people when they fall into kufr and shirk, and not to remain attached to them on account of tribal or blood ties. If this is the case with one's own people with whom a common lineage is shared, how much more so in the case of those with whom one shares nothing more than a superficial characteristic such as skin color!

... A Muslim's loyalty is determined, not by his skin colour, his tribal affiliation, or his last name but by his faith. He loves those whom Allah loves and hates those whom Allah 
hates. He forges alliances for the cause of Allah and breaks relations for the cause of Allah (Dabiq 2015c, p. 19).

In an opinion article in the French newspaper Le Monde, Piketty (2015) argues that inequality is a major driver of violent extremism in the Middle East, including the attacks on Paris and that Western nations have to carry some of the blame for that inequality. He contends that jihadists are motivated by economic inequity as well as the asymmetrical wars perpetuated by Western powers. His argument does not mean that extremists are recruited only from low income groups, on the contrary, Kruger's (2018) study of people who join extremist groups found that educated, middle-class people are as likely to be involved in terrorist events as people with little education and low incomes. What joins members of extremist groups is ideology and one part of that ideology is redressing inequality. Da'esh also appeals to the social values of those who oppose the bombings of civilians in Syria:

Atrocities committed by the Islamic State, he said, are aimed at "making the West get a taste of their own medicine," which part of him thinks the West deserves.

Ahmad Walid Rashidi, cited in New York Times, 24 April 2015

\subsection{A Regional Dispersal}

Two case studies analysed in this paper relate to a period when Da'esh was holding large swathes of territory in Iraq and Syria. One outcome of the Paris bombings was a concerted campaign in Iraq and Syria led by the governments of France, the United Kingdom and the United States. This resulted in a dramatic contraction in the lands controlled by Da'esh between 5 January 2015 and 8 January 2018 (Figure 7) and a dispersal of foreign fighters to other parts of the world.

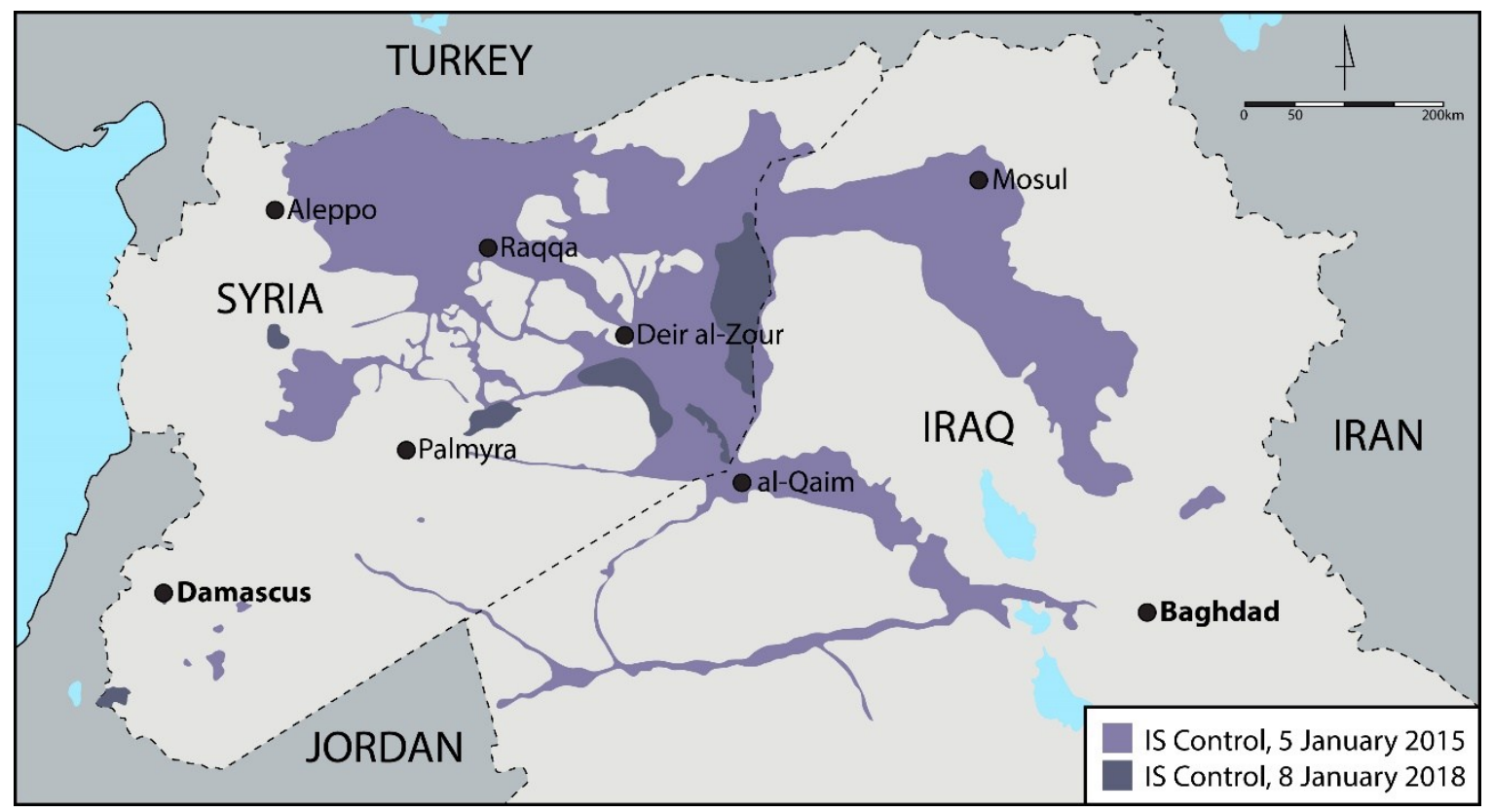

Figure 7. Contraction in the lands controlled by Da'esh/the Islamic State between 5 January 2015 and 8 January 2018. Source IH Conflict Monitor.

Da'esh's response to the loss of territory in Iraq and Syria in 2017 was to shift the focus to alternative fronts, including the Philippines:

If you find it difficult to go to Sham [greater Syria] because of cost and security concerns, why not try the Philippines? Truly, our brothers in the Philippines are awaiting your arrival, why are you so slow in answering their call? 
Does it make sense that we have a neighbour being attacked by a swarm of criminals but we aim for a further neighbor rather than one closer by? We give more importance to the further neighbour and make the closer one lower priority? Brothers, this is not to demean efforts to emigrate to Sham but to advise those of you who are still in the land of kafir but have not yet set out on your journey: if you find it hard to get to Syria, strengthen the ranks in the Philippines.

(Telegram appeal, 8 June 2017, cited in IPAC 2017a, p. 4)

\subsection{Significant Trends}

It is possible to identify a number of significant trends. Firstly, there is a weaponisation of social media, particularly by Da'esh. Kraidy (2017a) points to an aggressive media strategy that demoralises the enemy at the same time that it rallies allies, the weaponising of images and the use of 'savagery' because it attracts extensive media coverage. He argues that Da'esh 'has a clear media doctrine intended to do as much damage as its bullets and bombs.' Elsewhere, Kraidy $(2017 b, 2018)$ argues that Da'esh's visual warfare is best understood through the notion of a 'projectilic image' that mimics fast, lethal, penetrative objects. He contends that:

Using a visual repertoire provided by Hollywood film and the U.S. military and therefore familiar to American and global audiences, the Islamic State efficiently delivers its image-projectiles. Wrapping images of atrocity in a familiar visual and narrative format makes them more accessible and thus more potent, inflicting the effect of terror on viewers (Kraidy 2017a).

Secondly, social media is being used almost speculatively, to send an idea into the world and see if-and how-it resonates with global populations. Social media enables extremist organisations-directly or through their online communities - to inspire actions that can be carried out by individuals in their home countries. This capacity is well recognised by Da'esh, as indicated by published discussions regarding attacks that took place in Australia, Canada and the USA:

The significance of these attacks and others is enormous and cannot be underestimated. By calling on Muslims around the world to rise up in arms, the Shaykh launched attacks in Canada, America and Australia (three of the countries mentioned in his speech) with nothing more than words and a shared belief in the act of worship that is jihad. A general in a conventional army couldn't possibly hope to have such power over men he'd never met on the other side of the world, ordering them to attack and possibly be killed, even if he offered them money! (Cantlie 2014, p. 38).

Thirdly, both Da'esh and Hizb ut-Tahrir Indonesia exploit the capacity of social media to develop global allegiances and inspire action by individuals working alone:

So let every Muslim who wishes to taste the sweetness of walā' and barā' follow the example of Ibrāhīm and declare enmity towards the kuffār amongst his own people-whether black, white, Arab, or non-Arab-and then march forth and wage war against them with whatever means are available to him (Dabiq 2015c, p. 21).

As Michael (2013) points out, social media gathering points, such as electronic chat rooms, allow dispersed individuals to share information and develop a shared worldview and a common goal that can subsume local agendas. In Indonesia, the Institute for Policy Analysis of Conflict has identified an increasing willingness among Indonesian women to organise social media groups, set up fund-raising charities and provide various forms of logistical support for Islamic State. Reports from this Institute identify how social media has facilitated the arrangement and enactment of marriages between supporters, the recruitment of new supporters through religious study groups and the promotion of 
sympathetic religious teachers (IPAC 2017a). Social media has played a role in the radicalisation of Indonesian female domestic workers in Hong Kong and Singapore who sought to provide financial support for Da'esh (IPAC 2017b; Siu and Carvalho 2017) and in failed acts, such as the attempt by Ivan Armadi Hasugian to bomb a Catholic Church in Medan, North Sumatra, in August 2016. Hasugian stated that he made several contacts with people online and conducted a bai'at (pledge of allegiance) online before he was ready to commit the act and that he learned to assemble the bomb through the internet (IPAC 2017b, p. 14; Sulistyawati and Dwinanda 2017). His recruitment is similar to that of Akbar Maulana, whose story is filmed by Noor Huda Ismail in the movie Jihad Selfie (see Ismail 2016).

\subsection{What Can Be Done?}

The current situation presents challenges to all countries, whether they have Muslim minority or Muslim majority populations. It is clear that extremist ideologies are nurtured by conflicts in social, cultural and religious values and by the social and economic disparities that often underwrite such conflicts. Unless these conflicts are addressed Da'esh and Hizb ut-Tahrir-or variations-will continue to flourish.

What can be done? It is possible to identify two courses of action. The first is fostering the religious and cultural respect that underpins intercultural understandings, both within and between countries. These richer understanding make individuals and groups less open to manipulation by extremist groups and less likely to demonise other groups. The second course of action is to use the soft power of social media more effectively. Our case study on Indonesia provides a pertinent example of the effective use of soft power by prominent Muslim organisations to counter online radicalisation. Moreover, as Zaharna $(2007$, p. 221) points out, narratives that are supported by the soft power of cumulative, multicultural understandings have the capacity to attract and persuade across national, cultural and ethnic borders.

\subsection{The Soft Power of Social Media}

Social media holds solutions to the issues raised in this paper as well as complications. Torres Soriano (2012) and Benson (2014) contend that the internet creates as many vulnerabilities for terrorist organisations as it does strengths. On the one hand, networked media provides an array of unprecedented advantages for terrorist groups-interconnectivity, anonymity, cheapness, power enhancement, access to new audiences (e.g., Whine 1999). On the other hand, it also provides a host of disadvantages, chiefly opportunities for tracing and monitoring, hacking, individual and organisational attacks on sites, disinformation, confusion, counter claims, entrapment, paranoia and dilution (Torres Soriano 2012). As much as networked media facilitates communication between like-minded individuals, it also provides a forum for those who argue against it:

Jihadist groups seeking an intensive Internet presence must contend with the paradox that interaction with Web users allows them to attain their goals by creating a sense of virtual community, consisting of individuals who share and mutually reinforce their radical beliefs but at the same time the same instruments that nurture the cyber-community also open the door to dissident actions or critical voices who can gradually erode the ideological orthodoxy of the terrorist movement (Torres Soriano 2012, p. 273).

Successful counter-radicalisation, however, particularly of the disaffected, socially isolated or existentially frustrated, depends on reaching those who are most capable of making a difference within any given community, many of whom may themselves be dissenters in various ways (Spalek 2014). At a more general level, social media can provide a physically and emotionally safe space in which to discuss contentious issues. The capacity of social media to engender cross-cultural understandings is demonstrated in the following twitter conversation that took place on January 30, 2015 between Eleanor Robson, Vicious Assyrian and Dread Muslim: 
Dread Muslim: Walls are all you people care about.

Eleanor Robson: I have several dear friends \& colleagues in Mosul, worked with them for 25 years to help protect their cultural heritage. You?

Dread Muslim: I have several brothers and sisters in Syria worked with them to save their future from dying. Saved many years of their life.

Eleanor Robson: We're not so different; I use my professional skills to support life \& work of Iraqi friends who care about its past \& future.

Eleanor Robson: I agree that too many people care more about the past than the present but I'm not one of them.

Vicious Assyrian: Thank you.

Dread Muslim: May Allah guide You. Please forgive me if what I said sounded rude to you. Eleanor Robson: That's very generous; thank you. There's nothing to forgive though :) I've been feeling the same way today ...

This conversation is a fine example of social media redressing cultural distortions through the process of immediate and direct message exchange: even though the individuals are in widely different locations and have quite different backgrounds they are able to discuss a heated topic and resolve misinterpretations and misunderstandings that are, in essence, culturally based. As Zaharna (2007, p. 221) points out, the incorporation of culture into social media has the potential to become 'a rich source of team-coalition synergy' through creating consensus out of inherently conflicting positions. Narratives that are supported by the soft power of cumulative, multicultural understandings have the capacity to attract and persuade across national, cultural and ethnic borders (Zaharna 2007, p. 221). Holmes (2008, p. 532), in particular, argues for using the imagined reality of the internet as a means: 'to create solidarity across differences, to search for the common grounds of both oppression and liberation and ... to create consensus on the basis not of tradition but rather of invention, experimentation in reality and collective self-critique.'

\section{Conclusions}

This paper has identified a number of ways in Da'esh and Hizb ut-Tahrir Indonesia have been able to further their brands of socially mediated terrorism by exploiting conflicting cultural and religious values. Extremist groups are nurtured by conflict. Da'esh, in particular, is sophisticated in the manner in which it uses social, cultural and religious values to target specific audiences. It provides a model for other extremist organization, though the model has not yet been followed strongly by Hizb ut-Tahrir Indonesia. Sometimes, the symbolic responses of the opponents of extremist organisations can be predicted and some of these responses may inadvertently further extremist aims. When an attack happens, in the emotion of the moment, individuals wish to act. All of us need to be cautious, however, of symbolic reactions that signal division between Muslims and non-Muslims. We need emblems that act against the xenophobia that is a recruiting tool for jihadists. We need to be more aware of the role that cultural icons play in conflict situations. It is essential that we understand the diverse values of diverse people. Above all, we need greater understanding of and respect for, each other's social, cultural and religious values.

Author Contributions: C.S. conceived the basic ideas for this paper and is the primary author. R.v.d.B. and C.d.L. worked with her to focus the ideas. I.R. led in the development of signalling theory as the theoretical framework for this study. R.v.d.B., S.S., P.S. and I.W. broadened the data and analysis in relation to Indonesia and other parts of South-East Asia. B.I. broadened the data and analysis in terms of iconoclasm in Iraq and Syria. C.S. and C.d.L. led in writing the revision of the paper. All authors contributed substantially to the writing of this article.

Acknowledgments: We thank Antoinette Hennessy, who promptly assisted with the preparation of many of the figures used in this paper, even when she was in the field. Gary Jackson kindly assisted with the proof-reading of drafts. Jim Smith drew our attention to Da'esh's emulation of the heroic tropes of online gaming in their modelling of warrior images. This paper was improved by advice from an anonymous reviewer which helped us to fine-hone our arguments. We are very grateful to Kent R. Kerley, the guest editor of this issue, for editorial comments and 
advice and for inviting us to contribute to this special issue of Religions, entitled "Religion and Crime: Theory, Research and Practice." In Figure 1, the image of the Da'esh fighter is courtesy of the SITE Intelligence Group, while the image of InFamous was developed for IGN Entertainment games and is provided here courtesy of Jitrixis (Own work) [CC BY-SA 4.0 (http:/ / creativecommons.org/licenses/by-sa/4.0)], via Wikimedia Commons. Figure 2 is courtesy of the SITE Intelligence Group. The photo in Figure 3 of das Neue Rathaus (New City Hall) in Hannover is by Nifoto (Own work) [CC BY-SA 4.0 (http:/ / creativecommons.org/licenses/by-sa/4.0)], via Wikimedia Commons. The Facebook images in Figure 3 are produced courtesy of Claire Smith's sister, Jo Smith, Executive Director, Australian Guild of Screen Composers and visual artist and activist Charlotte Farhan, who is editor of editor of ASLI and this stands for Art Saves Lives International Magazine. In Figure 4, the image of Temple of Bel, Palmyra, Syria, in December 2008 is courtesy of Yvonnefm-Own work, CC BY-SA 3.0, https: / / commons.wikimedia.org/w/index.php?curid=5443673 from Wikimedia Commons. In Figure 5, the image of the Islamic State/D'aesh is in the Public Domain, https://commons.wikimedia.org/w/index.php? curid $=11854957$ while the image of the flag of Hizb ut-Tahrir is attributed to Dn9ahx at en.wikipedia [CC0], from Wikimedia Commons. The image of Hizbut Tahrir Indonesia in Figure 6 is courtesy of Freedom House and Wikimedia Commons. The map showing contraction in the lands controlled by Da'esh/the Islamic State between 5 January 2015 and 8 January 2018 is courtesy of IHS Conflict Monitor.

Conflicts of Interest: The authors declare no conflict of interest.

\section{References}

Baram, Amatzia. 1991. Culture, History and Ideology in the Formation of Ba'thist Iraq, 1968-1989. Londn: Macmillan. Barnard, Anne, and Hwaida Saad. 2015. ISIS Claims Responsibility for Blasts That Killed Dozens in Beirut. New York Times, November 12. Available online: http:/ /www.nytimes.com/2015/11/13/world/middleeast/ lebanon-explosions-southern-beirut-hezbollah.html(accessed on 18 May 2018).

Benson, David. 2014. Why the Internet is not increasing terrorism. Security Studies 23: 293-328. [CrossRef]

Bokova, Irina. 2015. UNESCO Director General Condemns Destruction of Nimrud in Iraq. UNESCO Media Services, March 6. Available online: https:/ / en.unesco.org/news/unesco-director-general-condemns-destructionnimrud(accessed on 18 May 2018).

Bourdieu, Pierre. 1977. Outline of a Theory of Practice. Cambridge: Cambridge University Press.

Brokensha, Haley, Lina Eriksson, and Ian Ravenscroft. 2016. Charity, signaling and welfare. Politics, Philosophy and Economics 15: 3-19. [CrossRef]

Bulbulia, Joseph, and Richard Sosis. 2011. Signalling theory and the evolution of religious cooperation. Religion 41: 363-88. [CrossRef]

Cameron, David. 2015. Prime Minister David Cameron's Statement Following the Terrorist Attack in Paris. Available online: https://www.gov.uk/government/news/prime-minister-statement-on-paristerror-attack (accessed on 18 May 2018).

Cantlie, John. 2014. If I were the US President today... Remaining and Expanding. Dabiq 5: 36-39.

Charbonneau, Louis. 2015. U.N. Condemns Islamic State’s ‘Barbaric Terrorist Acts' in Iraq. Reuters, February 27.

Coller, Ian. 2015. Why Paris? The Conversation. Available online: https://theconversation.com/why-paris-50736? (accessed on 18 May 2018).

Colwell-Chanthaphonh, Chip. 2002. Dismembering/disremembering the Buddhas? Renderings on the internet during the Afghan purge of the past. Journal of Social Archaeology 3: 75-98. [CrossRef]

Dabiq. 2014. Ramadan 1435 [June/July 2014]. Khilafah declared. The Return of Khilafah Dabiq 1: 6-11.

Dabiq. 2015a. Jumada Al-Akhirah 1436 [March/April 2015]. Erasing the legacy of a ruined nation. Shari'ah Alone Will Rule Africa Dabiq 8: 22-24.

Dabiq. 2015b. Ramadan 1436 [June/July 2015]. From the pages of history: The expeditions, battles and victories of Ramadan. The Laws of Allah or the Laws of Men Dabiq 10: 26-29.

Dabiq. 2015c. Ramadan 1436 [August/September 2015]. From the Battle of Al-Ahzab to the War of Coalitions. Dabiq 11.

Danti, Michael D., Richard L. Zettler, Cheikhmous Ali, Tate Paulette, Abdalrazzaq Moaz, Allison Cuneo, David Elitzer, and Danny Breegi. 2015. Weekly Report 30 ASOR Cultural Heritage Initiatives. Boston: American Schools of Oriental Research (ASOR).

De Cesari, Chiara. 2015. Post-colonial Ruins: Archaeologies of Political Violence and Da'esh. Anthropology Today 31: 22-26. [CrossRef]

De Saussure, Ferdinand. 1983. Course in General Linguistics. Translated by Roy Harris. London: Duckworth. First published 1916. 
Dragovic, Denis. 2015. ISIS, ISIL, Islamic State or Da'esh? The Conversation. Available online: https:// theconversation.com/explainer-isis-isil-islamic-state-or-Da $\backslash \mathrm{T} 1 \backslash$ textquoterightesh-40838 (accessed on 18 May 2018).

Gamboni, Dario. 2001. World Heritage: Shield or Target? The Getty Conservation Institute Newsletter 16: 5-11.

Giddens, Anthony. 1984. The Constitution of Society: Outline of the Theory of Structuration. Berkeley: University of California Press.

Guilford, Tim, and Marion Stamp Dawkins. 1991. Receiver psychology and the evolution of animal signals. Animal Behavior 42: 1-14. [CrossRef]

Holmes, Brian. 2008. Swarmachine. Third Text 22: 525-34. [CrossRef]

Horton, Helena. 2015. Paris Attacks: How to Change Your Facebook Profile Picture and Other Ways You Can Help. The Telegraph, November 15. Available online: https:/ /www.telegraph.co.uk/news/worldnews/ europe/france/11996735/Paris-attacks-How-to-change-your-Facebook-profile-picture-and-other-waysyou-can-help.html(accessed on 18 May 2018).

House of Commons. 2015. Daily Hansard.12 Feb 2015: Column 1002: Destruction of Historic Sites (Syia and Iraq). Available online: https:/ / publications.parliament.uk/pa/cm201314/cmselect/cmhaff/231/231.pdf (accessed on 17 May 2018).

House of Commons Home Affairs Committee. 2014. Counter-Terrorism. Seventeenth Report of Session 2013-14. HC231. Available online: https:/ / publications.parliament.uk/pa/cm201314/cmselect/cmhaff/231/231.pdf (accessed on 18 May 2018).

Indonesia Ministry of Communication and Information. 2018. Penguna Internet di Indonesia 63 Juta Orang (Internet Users in Indonesia 63 Milllion People). Available online: https:/ / www.kominfo.go.id/ content/detail/3415/kominfo-pengguna-internet-di-indonesia-63-juta-orang/0/berita_satker (accessed on 18 May 2018).

Institute for Policy Analysis of Conflict (Indonesia) (IPAC). 2017a. Marawi, the 'East Asia Wilayah' and Indonesia. Report No. 38. Available online: http:/ / file.understandingconflict.org/file/2017/07/IPAC_Report_38.pdf (accessed on 17 May 2018).

Institute for Policy Analysis of Conflict (Indonesia) (IPAC). 2017b. The Radicalisation of Indonesian Women Workers in Hong Kong. Report No. 39. Available online: http:/ / file.understandingconflict.org/file/2017/ 07/IPAC_Report_39.pdf (accessed on 18 May 2018).

Isakhan, Benjamin. 2018. The Islamic State attacks on Shia holy sites and the 'Shrine Protection Narrative': Threats to sacred space as a mobilization frame. Terrorism and Political Violence. [CrossRef]

Isakhan, Benjamin, and Antonio Zarandona. 2017. Erasing History: Why Islamic State Is Blowing up Ancient Artefacts. The Conversation, June 5. Available online: https:/ / theconversation.com/erasing-history-whyislamic-state-is-blowing-up-ancient-artefacts-78667(accessed on 18 May 2018).

Isakhan, Benjamin, and Antonio Zarandona. 2018. Layers of religious and political iconoclasm under the Islamic State: Symbolic sectarianism and pre-monotheistic iconoclasm. International Journal of Heritage Studies 24: 1-16. [CrossRef]

Ismail, Noor Huda. 2016. Jihad Selfie. Available online: https://www.youtube.com/watch?v=JUpjomQZt2A (accessed on 17 May 2018).

Kraidy, Marwan M. 2017a. This Is Why the Islamic State Shocks the World with Its Graphically Violent Imagery. The Monkey Cage. Available online: https:/ / www.washingtonpost.com/news/monkey-cage/wp/2017/02/ 09/this-is-why-the-islamic-state-shocks-the-world-with-its-graphically-violent-imagery/?utm_term= .ebc2fdbb24b7 (accessed on 18 May 2018).

Kraidy, Marwan M. 2017b. The projectilic image: Islamic State's digital visual warfare and global networked affect. Media, Culture and Society 39: 1194-209. [CrossRef]

Kraidy, Marwan M. 2018. Fun against fear in the Caliphate: Islamic State's spectacle and counter-spectacle. Critical Studies in Media Communication 35: 40-56. [CrossRef]

Kruger, Alan B. 2018. What Makes a Terrorist: Economics and the Roots of Terrorism. Princeton: Princeton University Press.

Lavender, Jane. 2015. Paris Attacks: Why This Woman Won't Change Her Facebook Profile to France Flag. Mirror, November 16. Available online: http:/ / www.mirror.co.uk/news/world-news/paris-attacks-woman-wontchange-6837570(accessed on 18 May 2018).

Leander, Anna. 2016. Digital/commercial (in)visibility: The politics of DA'ESH recruitment videos. European Journal of Social Theory 16: 326-41. [CrossRef] 
Letsch, Constanze, and Nadia Khomami. 2015. Turkey Terror Attack: Mourning after Scores Killed in Ankara Blast. The Guardian. Available online: https:/ /www.theguardian.com/world/2015/oct/10/turkey-suicidebomb-killed-in-ankara(accessed on 18 May 2018).

Michael, George. 2013. The new media and the rise of exhortatory terrorism. Strategic Studies Quarterly 2013: $40-68$.

Miles, Kathleen. 2015. Queen Rania: Let's Drop the First I in ISIS: There's Nothing Islamic about Them. The Huffington Post. Available online: http://www.huffingtonpost.com/2015/03/06/queen-rania-isisislamic_n_6781160.html(accessed on 18 May 2018).

Muhammadiyah. 2018. Muhammadiyah. Available online: http://www.muhammadiyah.or.id/ (accessed on 18 May 2018).

Murray, Michael J., and Lyn Moore. 2009. Costly signalling and the origin of religion. Journal of Cognition and Culture 9: 229-45. [CrossRef]

Nahdlatul Ulama. 2017. Pelajar NU Mojowarno Penuhi Facebook Dengan Status Dakwah Ramah. Available online: http:/ / www.nu.or.id/post/read/78373/pelajar-nu-mojowarno-penuhi-facebook-dengan-statusdakwah-ramah (accessed on 18 May 2018).

Nahdlatul Ulama. 2018. Suara Nahdlatul Ulama/The Voice of Nahdlatul Ulama. Available online: http:/ / www. nu.or.id/ (accessed on 18 May 2018).

Obama, Barack. 2015. President Obama Offers a Statement on the Attacks in Paris. Available online: https: / / obamawhitehouse.archives.gov/blog/2015/11/13/watch-president-obamas-statement-attacks-paris (accessed on 18 May 2018).

Piketty, Thomas. 2015. Clamping down with Law and Order Will Not Be Enough. Available online: http:/ / piketty. blog.lemonde.fr/2015/11/24/clamping-down-with-law-and-order-will-not-be-enough/ (accessed on 18 May 2018).

Resnyansky, Lucy. 2015. Social media data in the disaster context. Prometheus. [CrossRef]

Rodriguez, Rachel. 2015. After Paris Massacre, the World Turns Blue, White and Red for France. CNN, November 14. Available online: http:/ / edition.cnn.com/2015/11/14/world/paris-attacks-tributes-irpt/(accessed on 18 May 2018).

Rubino, Rubino, Hatta Hatta, and Abdullah Abdullah. 2017. Communication technique of Hizbut Tahrir Indonesia (HTI) in the development of cadre in North Sumatera. International Journal on Language, Research and Education Studies 1: 240-55.

Setiawan, Zudy. 2018. Relasi penerimaan pancasila oleh ormas keagamaan terhadap pengokohan nasionalisme dan kerukunan antar umat beragama (Studi Kasus Nahdlatul Ulama dan Hizbut Tahrir Indonesia). Socio Dialktika 2: 1-15.

Shahab, Sofya, and Benjamin Isakhan. 2018. The ritualization of heritage destruction under the Islamic State. Journal of Social Archaeology. [CrossRef]

SITE Intelligence Group Enterprise. 2015. Jihadists on Twitter Celebrate Attacks in Paris, Speculate Who Planned Them. Available online: https://ent.siteintelgroup.com/Jihadist-News/jihadists-on-twitter-celebrateattacks-in-paris-speculate-who-planned-them.html (accessed on 18 May 2018).

Siu, Phila, and Raquel Carvalho. 2017. About 20 Indonesian Domestic Workers on Hong Kong Police Watch List over Islamic State Links. South China Morning Post, August 13. Available online: http:/ / www.scmp.com/news/hong-kong/law-crime/article/2106612/20-indonesian-domesticworkers-hong-kong-police-watch-list(accessed on 18 May 2018).

Smith, Claire. 2015. Social media and the destruction of World Heritage sites as global propaganda. In Proceedings of II International Conference on Best Practices in World Heritage: People and Communities. Mahón, Menorca, Balearic Islands, Spain, April 29 to May 2 2015. Edited by Mena Alicia Castillo. Madrid: Universidad Complutense de Madrid, pp. 27-49.

Smith, Claire, Heather Burke, Cherrie de Leiuen, and Gary Jackson. 2016. The Islamic State's Symbolic War: Da'esh's Socialy Mediated Terrorism as a Threat to Cultural Heritage. Journal of Social Archaeology 16: 164-88. [CrossRef]

Spalek, Basia. 2014. Community engagement for counterterrorism in Britain: An exploration of the role of 'connectors' in countering Takfiri Jihadist terrorism. Studies in Conflict E Terrorism 37: 825-41. 
Sulistyawati, Laeny, and Reiny Dwinanda. 2017. Perpetrator Learns to Assemble Bomb through Internet. Republika. Available online: http:/ / en.republika.co.id/berita/en/national-politics/16/08/29/ocohfe414-perpetratorlearns-to-assemble-bomb-from-the-internet (accessed on 18 May 2018).

The Associated Press. 2015. Iraq: Suicide Bomb and Road Blast Kill 26 in Baghdad. New York Times. Available online: http:/ / www.nytimes.com/2015/11/14/world/middleeast/iraq-suicide-bomb-and-road-blast-kill26-in-baghdad.html(accessed on 18 May 2018).

Torres Soriano, Manuel R. 2012. The vulnerabilities of online terrorism. Studies in Conflict E Terrorism 35: $263-77$. UNESCO. 2015. Director-General Condemns the Destruction of the Arch of Triumph in Palmyra. Paris: United Nations Educational, Scientific and Cultural Organization.

Wedeen, Lisa. 1999. Ambiguities of Domination: Politics, Rhetoric and Symbols in Contemporary Syria. Chicago: University of Chicago Press.

Whine, Michael. 1999. Cyberspace-A new medium for communication, command and control by extremists. Studies in Conflict E Terrorism 22: 231-45.

Winter, Tim. 2014. Beyond Eurocentrism? Heritage conservation and the politics of difference. International Journal of Heritage Studies 20: 123-37. [CrossRef]

Worley, Will. 2016. Palmyra: Photographer's Powerful Before and after Photos Show City's Destruction at Hands of ISIS. Available online: https://www.independent.co.uk/news/world/middle-east/palmyrasyria-photos-new-palmyra-photos-show-devastation-of-artefacts-ruined-by-isis-a6964766.html (accessed on 18 May 2018).

Yuniarni, Sarah. 2018. Indonesia Had 143m Internet Users in 2017: APJII. Jakarta Post, February 19. Available online: http:/ /jakartaglobe.id/business/indonesia-143m-internet-users-2017-apjii/(accessed on 18 May 2018).

Zaharna, Rhonda. 2007. The soft power differential: Network communication and mass communication in public diplomacy. The Hague Journal of Diplomacy 2: 213-28. [CrossRef]

Zahavi, Amotz. 1975. Mate selection: A selection for a handicap. Journal of Theoretical Biology 53: 205-14. [CrossRef] Zahavi, Amotz. 1997. The Handicap Principle. Oxford: Oxford University Press.

(C) 2018 by the authors. Licensee MDPI, Basel, Switzerland. This article is an open access article distributed under the terms and conditions of the Creative Commons Attribution (CC BY) license (http:/ / creativecommons.org/licenses/by/4.0/). 